\title{
ERRATUM
}

\section{In Vitro Epsilon RNA-Dependent Protein Priming Activity of Human Hepatitis B Virus Polymerase}

Scott A. Jones, Rajeev Boregowda, Thomas E. Spratt, and Jianming Hu

Department of Microbiology and Immunology, The Penn State University College of Medicine, Hershey, Pennsylvania, USA, and Department of Biochemistry and Molecular Biology, The Penn State University College of Medicine, Hershey, Pennsylvania, USA

Volume 86, no. 9, p. 5134-5150, 2012. Page 5136, column 1, line 14 from the top: “ $5 \mu \mathrm{g} / \mu$ l leupeptin” should read “ $5 \mu \mathrm{g} / \mathrm{ml}$ leupeptin.” 